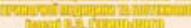

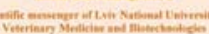

15

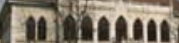

int

Q.9.

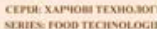

Том 21 Nis 91

2019
Науковий вісник Дьвівського національного університету ветеринарної медицини та біотехнодогій імені С.3. Гжицького. Серія: Харчові технології

\section{Scientific Messenger of Lviv National University} of Veterinary Medicine and Biotechnologies.

Series: Food Technologies

ISSN 2519-268X print

https://nvlvet.com.ua/index.php/food

doi: 10.32718/nvlvet-f9110

UDC 664.661.016/.019:664.236

\title{
New Products Based on Spelt for Restaurant Sector
}

\author{
O.S. Sakhno, O.O. Hryshchuk, Y.P. Furmanova, O.S. Pavliuchenko \\ National University of Food Technologies, Kyiv, Ukraine
}

Article info

Received 18.01.2019

Received in revised form 15.02 .2019

Accepted 18.02.2019

National University of Food Technologies,

Volodymyrska Str., 68

Kyiv, 01033, Ukraine.

Tel.: +38-093-986-05-44

E-mail:Furmanovajp@ukr.net
Sakhno, O.S., Hryshchuk, O.O., Furmanova, Y.P., \& Pavliuchenko, O.S. (2019). New Products Based on Spelt for Restaurant Sector. Scientific Messenger of Lviv National University of Veterinary Medicine and Biotechnologies. Series: Food Technologies, 21(91), 54-59. doi: $10.32718 /$ nvlvet-f9110

The spelt processed products that are presented on the Ukrainian food market have been analyzed in the paper. The comparative characteristics of chemical composition of spelt products - wholemeal flour, grits, flakes, bran - with same wheat and oat products have been investigated. Spelt flour and flakes are proposed for applying at the restaurant establishments. Authors havedeveloped technology of baked products for special dietician consumption - spelt crisp bread and spelt sweet bar as well. Spelt crisp bread contains linseed, sunflower seed, spices (cilantro, curcuma), herbs (fennel, parsley). Technology of this bread includes such operations as grinding of cleaned seeds, sifting of bran and flour, mixing of dry components, adding of kefir and water. Duration of first fermentation is 20 minutes, then rectangular shaping $(5 \times 13 \mathrm{~cm})$ and drying at $80^{\circ} \mathrm{C}$ during $4 \ldots 5$ hours, then cooling at ambient temperature near $30 \mathrm{~min}$. Caloric value of spelt crisp bread is $260 \mathrm{kCal}$. Sensorial parameters of spelt crisp bread - rectangular shape, light brown colour, smooth top with inclusion of linseed and sunflower seed, pleasant taste and spicy aroma, crisp crust and thick texture. Sweet spelt bar is an example of beneficial sweets. It contains sunflower seed and pumpkin seed, nuts (walnut and almond), date, honey and sesame. Caloric value of spelt sweet bar is $220 \mathrm{kCal}$. Technology of this bread includes such operations as drying of spelt flakes at $120^{\circ} \mathrm{C}$ during 2 min and further cooling, soaking of date in hot water during $3 \mathrm{~min}$, removing of stone and grinding. Walnut is inspected due to the absence of walnut shell, almond is soaking for 3 hours, then parboiled and grinded. All ingredients are mixed during 5 min with honey. Then bar is rectangular shaping and served. Such bar has rectangular shape, ribbed top, crisp texture, light brown colour and intense walnut aroma.

Key words: spelt flour, spelt flakes, crackers made from spelt flour, spelt flakes bars.

\section{Нова продукція на основі спельти для ресторанного господарства}

\author{
О.С. Сахно, О.О. Грищук, Ю.П. Фурманова, О.С. Павлюченко \\ Національний університет харчових технологій, м. Київ, Украӥна
}

Проаналізовано представлені на ринку Украӥни продукти переробки зерна спельти. Серед них борошно иільнозернове, крупи, пластівиі, висівки. Наведено порівняльну характеристику їх хімічного складу із аналогічними продуктами із зерна пшениці та вівса. Запропоновано використання борошна і пластівиів зі спельти у закладах ресторанного господарства. Розроблено технологію виробничтва хлібних виробів для спечіального дієтичного споживання - хлібиів із борошна спельти та кондитерських виробів - батончиків із пластівців спельти. Хлібці у своєму складі містять насіння льону та сонямника; прянощі (коріандр, куркуму); зелень (кріп і петрушку). Технологія приготування хлібиів полягає у наступному: попередньо очищене насіння подрібнюють. Висівки і борошно просіюють. Усі сухі компоненти перемішують, додають кефір та воду. Замішують тісто, яке вистоюється 20 хв. Потім розкачують хлібиі прямокутної форми $5 \times 13$ см та висушують їх при $t=80{ }^{\circ} \mathrm{C} \mathrm{протягом} 4$...5 год. Охолоджують за кімнатної температури протягом 30 хв. Калорійність отриманих хлібців складає 260 ккал. Готові хлібиі мають прямокутну форму, світло-коричневий колір, рівну поверхню, на якій проглядається насіння льону та соняшника. Їм притаманний приємний смак та аромат прянощів. Вони мають хрумку, щільну консистенцію. Батончики є прикладом корисних солодощів. Вони містять у своєму складі насіння соняшника і гарбуза; горіхи (грецькі і мигдаль); фініки, мед і кунжут. Калорійність батончиків із пластівиів спельти складає 220 ккал. Технологія виробництва батончиків із пластівців спельти полягає у наступному: пластівці зі спельти підсу- 
иують у пароконвектоматі 2 хв при температурі $120{ }^{\circ} \mathrm{C}$, охолоджують до кімнатної температури. Фініки замочують у теплій воді на 3 хв, висушують паперовим рушником, видаляють кісточку, подрібнюють. Волоські горіхи та насіння перебирають, контролюють на відсутність шкарлупи та іниих сторонніх частинок. Мигдаль замочують на 3 год, обсушують паперовим рушником. Насіння та горіхи бланшують, висушують паперовим рушником, подрібнюють. У чисту суху ємність кладуть усі підготовлені інгредієнти, додають мед та ретельно перемішують 5 хв. Потім формують батончик прямокутної форми, і подають. Батончики із пластівців спельти мають прямокутну форму, рифлену без трішин поверхню; хрумку консистенцію, світло-коричневий колір і виражений горіховий аромат.

Ключові слова: борошно спельти, пластівцฺі спельти, хлібиі із борошна спельти, батончики з пластівціів спельти.

\section{Вступ}

Здоровий спосіб життя, як ніколи, сьогодні дуже популярний серед українців. Усе більше людей, окрім смаку, аналізують корисність харчових продуктів. 3 іншого боку, продукти переробки зерна складають вагому частку харчування українців. Тому стає зрозумілим зростання популярності такої прадавньої зернової культури, як спельта (Shewry, 2018). Учені одностайно відносять спельту до органічних зернових культур, які не підлягали генній модифікації та не потребують використання мінеральних добрив для їх вирощування. Спельту можна порівняти із м'якою пшеницею (Ranhorta et al., 1995; Golik, 2012). ÏÏ наукова назва Triticum spelta, міжнародна - Spelta, окрім того, в Італії спельту називають Farro grande, у Польщі - Orkisz, у Німеччині - Dinkel.

Спельта, порівняно 3 традиційними видами пшениці, має підвищений вміст білків, ліпідів, харчових волокон, вітамінів та мінеральних речовин. Поживні речовини спельти мають високий рівень розчинності, тому вони легше та швидше засвоюються організмом. Засвоюваність білків спельти краща, ніж у пшениці (Bul'chuk \& Nikulin, 2008). Порівняльна характеристика хімічного складу зерна спельти і зерна пшениці свідчить на користь першої. Багатший вітамінний та мінеральний склад спельти науковці пояснюють ii здатністю краще за голозерні пшениці поглинати поживні речовини з грунту (Bonafaccia et al., 2000).

В Україні, в Уманському національному університеті садівництва, під керівництвом селекціонерагенетика Парія Ф.М. виведено вітчизняні сорти спельти - “Зоря України” та “Європа”.

Асортимент продуктів переробки зерна спельти на ринку України представлений борошном цільнозерновим, пластівцями, висівками. На вітчизняних полицях супермаркетів можливо знайти спельтове обойне борошно ТМ “Зелений млин” (ТОВ “Буртехпостач”) та ТМ “Екород” (“Органік Оригінал”), спельтові пластівці - ТМ “Козуб”, крупи зі спельти - ТМ “Екород”.

Науковцями вивчається можливість використання борошна зі спельти у хлібопекарстві (Bul'chuk \& Nikulin, 2008). Нами запропонована технологія виробництва продукції в умовах закладів ресторанного господарства: батончиків із пластівців спельти та хлібців із борошна спельти.

\section{Матеріал і методи досліджень}

Застосовувалися загально прийняті методи досліджень. Борошно аналізували на кількість і якість клейковини, у пластівцях досліджували товщину, тривалість варіння. Клейковина відмивалася ручним способом за стандартною технологією згідно ГОСТ 27839-88 Міждержавний стандарт. "Борошно пшеничне. Методи визначення кількості і якості клейковини” та ДСТУ ISO 21415-1:2009 "Пшениця та пшеничне борошно. Вміст клейковини. Частина 1. Визначення сирої клейковини ручним способом”. Дослідження проводили у навчальних лабораторіях НУХТ. Вологість батончиків із пластівців спельти визначали термогравіметричним методом.

\section{Результати та їх обговорення}

Було проаналізовано борошно спельти і пшениці різних торгівельних марок: зразок № 1: обойне борошно спельти ТМ “Зелений млин”, зразок № 2: обойне борошно спельти ТМ “Лавка традицій”, зразок № 3: обойне борошно спельти ТМ "Екород" органічне, зразок № 4: обойне борошно пшеничне “Козуб” (контроль).

За критерій порівняння було обрано кількість i якість клейковини борошна. Результати досліджень наведено у табл. 1.

\section{Таблиця 1}

Дослідження кількості та якості клейковини борошна

\begin{tabular}{|c|c|c|c|c|}
\hline \multirow[b]{2}{*}{ Показники } & \multicolumn{4}{|c|}{ Досліджувані зразки борошна } \\
\hline & Зразок № 1 & Зразок № 2 & Зразок № 3 & $\begin{array}{l}\text { Зразок № } 4 \\
\text { Контроль }\end{array}$ \\
\hline Кількість клейковини, \% & 29 & 32 & 32 & 24 \\
\hline $\begin{array}{l}\text { Пружність на приладі } \\
\text { ІДК, од.ІДК }\end{array}$ & 90 & 92 & 105 & 74 \\
\hline Група якості клейковини & $\begin{array}{c}\text { II група - клейковина } \\
\text { задовільно слабка }\end{array}$ & $\begin{array}{c}\text { II група - клейковина } \\
\text { задовільно слабка }\end{array}$ & $\begin{array}{c}\text { III група - клейковина } \\
\text { незадовільно слабка }\end{array}$ & $\begin{array}{c}\text { I група - клейковина } \\
\text { хороша }\end{array}$ \\
\hline Розтяжність, см & 26 & 21 & 28 & 14 \\
\hline Колір & $\begin{array}{c}\text { Світлий з сірим } \\
\text { відтінком }\end{array}$ & $\begin{array}{c}\text { Світлий з сірим відтін- } \\
\text { ком }\end{array}$ & $\begin{array}{c}\text { Світлий з сірим відтін- } \\
\text { ком }\end{array}$ & Світлий \\
\hline
\end{tabular}


Аналіз даних, наведених в табл. 1, показав, що за кількісним вмістом клейковини борошно спельти краще за пшеничне борошно. Проте клейковина спельти слабка і більш розтяжна за пшеничну. Саме тому доречним буде використати борошно спельти у рецептурі (технології приготування) хлібців. Це бездріжджові хлібні вироби і міцність клейковини для них не така важлива. 3 іншого боку використання борошна спельти покращить хімічний склад хлібців, що важливо у виробах для спеціального дієтичного споживання.

Нами запропоновано технологію виробництва борошняних спельтових хлібців для ЗРГ. Рецептура наведена у табл. 2.

\section{Таблиця 2}

Рецептура хлібців із борошна спельти

\begin{tabular}{clcc}
\hline № & Найменування сировини & Брутто, г & Нетто,г \\
3/п & Борошно спельти & 44 & 44 \\
\hline 1 & Висівки спельти & 9 & 8,4 \\
2 & Насіння льону & 7 & 7 \\
3 & Насіння соняшника & 10 & 10 \\
4 & 0,1 & 0,1 \\
5 & Сіль & 30 & 30 \\
6 & Кефір 2,5\% & 0,1 & 0,1 \\
7 & Коріандр & 0,2 & 0,2 \\
8 & Кріп & 0,1 & 0,1 \\
9 & Петрушка & 0,1 & 0,1 \\
10 & Куркума & 30 & 30 \\
11 & Вода & 130 & 130 \\
12 & Вихід напівфабрикату & & 100 \\
& Вихід & & \\
\hline
\end{tabular}

Технологія приготування хлібців полягає у наступному: попередньо очищене насіння подрібнюють. Висівки і борошно просіюють. Усі сухі компоненти перемішують, додають кефір та воду. Замішують тісто, яке вистоюється 20 хв. Потім розкачують хлібці прямокутної форми $5 \times 13 \mathrm{~cm}$ та висушують їх при $\mathrm{t}=80{ }^{\circ} \mathrm{C}$ протягом 4..5 год. Охолоджують за кімнатної температури протягом 30 хв.

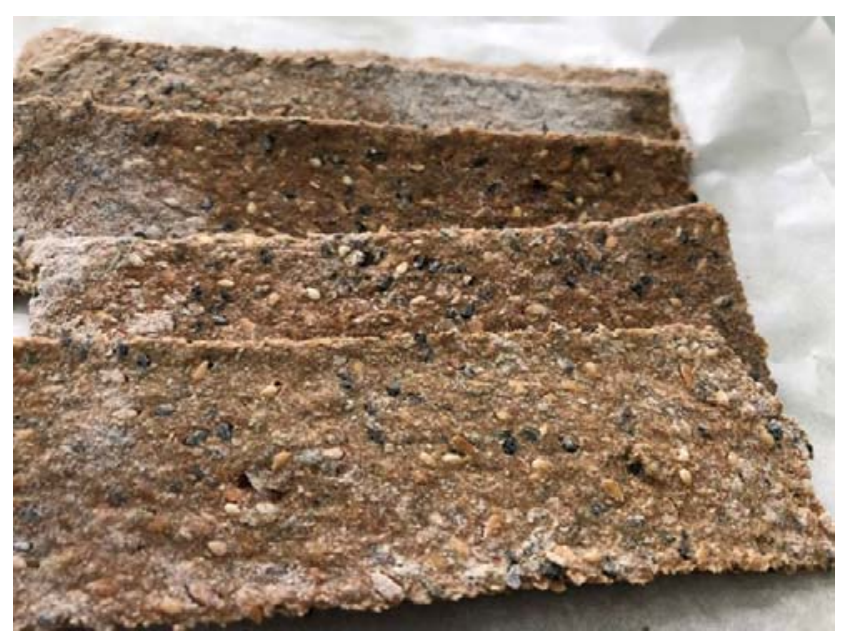

Рис. 1. Зовнішній вигляд хлібців із борошна спельти
Готові вироби досліджували за органолептичними та фізико-хімічними показниками. Розраховували калорійність хлібців із борошна спельти, вона складає 260 ккал. Результати досліджень наведено на рис. 1 та у табл. 3 .

\section{Таблиця 3}

Органолептичні показники якості хлібців з борошна спельти

\begin{tabular}{ll}
\hline Показник & \multicolumn{1}{c}{ Характеристика } \\
\hline Форма & Прямокутна, рівна форма хлібців \\
Поверхня & Не підгоріла, без здуття, міхурців, видно \\
Колір & Свіня соняшника, льону та спеції \\
Смак & Приємний, з присмаком прянощів та насіння \\
Запах & Приємний, з ароматом прянощів \\
Вигляд на & Добре висушений, не рівний \\
зламі & \\
\hline
\end{tabular}

Наступним кроком було порівняння якості пластівців спельти, пшениці та вівса 3 метою дослідження можливості створення батончиків із пластівців спельти для ЗРГ. Порівняльна характеристика пластівців наведена у табл. 4.

\section{Таблиця 4}

Порівняльна характеристика хімічного складу та біологічної цінності пластівців

\begin{tabular}{|c|c|c|c|}
\hline \multirow{2}{*}{ Показники на 100 г } & \multicolumn{3}{|c|}{ Пластівці } \\
\hline & Спельти & Вівсяні & Пшеничні \\
\hline Жири & 2,7 & 6,5 & 1,5 \\
\hline Насичені жирні кислоти & 0,2 & 1,16 & 0,27 \\
\hline Вуглеводи & 63,0 & 69,0 & 69,7 \\
\hline Цукор & 0,8 & 3,7 & 2,5 \\
\hline Білок & 11 & 10,76 & 11,9 \\
\hline Сіль & 0 & 0,001 & 0,01 \\
\hline \multicolumn{4}{|c|}{ Вітаміни } \\
\hline Вітамін В1, мг & 0,36 & 0,43 & 0,18 \\
\hline Вітамін В3, мг & 6,84 & 3,81 & 1,0 \\
\hline Вітамін В9, мкг & 45 & 87 & 32 \\
\hline Вітамін Е, мг & 0,79 & 0,22 & 0,1 \\
\hline \multicolumn{4}{|c|}{ Мінерали, мг } \\
\hline Залізо & 4,44 & 6,8 & 12,5 \\
\hline Магній & 136 & 112 & 88,5 \\
\hline Фосфор & 401 & 320 & 335 \\
\hline Калій & 388 & 321 & 290 \\
\hline Цинк & 3,28 & 3,1 & 1,8 \\
\hline Кальцій & 27 & 53,1 & 32,7 \\
\hline $\begin{array}{l}\text { Енергетична цінність } \\
\text { на } 100 \text { (г) продукту }\end{array}$ & 338 & 381 & 348 \\
\hline
\end{tabular}

Аналіз табл. 4 показав, що пластівці спельти кращі за рядом показників від вівсяних і пшеничних пластівців. Так пластівці спельти мають вищий вміст вітаміну В3 на 44 і 85\%, магнію на 18 і 35\%, фосфору на 20 і 17\%, калію на 5 і 25\%, цинку на 6 і 45\%. При цьому калорійність пластівців спельти нижча. Таким чином, замінивши вівсяні пластівці на пластівці спельти, може бути знижена калорійність, але покращена біологічна цінність готового продукту.

Було досліджено органолептичні показники пластівців після доведення їх до готовності шляхом варін- 
ня у воді. Час варіння обирали у відповідності із зазначеним на упаковці продуктів. Результати досліджень наведені у таблицях 5 і 6.

\section{Таблиця 5}

Порівняльна характеристика розварюваності пластівців

\begin{tabular}{lcc}
\hline Вид пластівців & Час варіння, хв & $\begin{array}{c}\text { Коефіцієнт розва- } \\
\text { рюваності }\end{array}$ \\
\hline Спельти & 10 & 1,9 \\
Вівсяні & 10 & 2,0 \\
Пшеничні & 5 & 2,1 \\
\hline
\end{tabular}

Аналіз даних табл. 5 і табл. 6 показав, що пластівці спельти мають найменший коефіцієнт розварюваності та дещо темніший колір, ніж вівсяні і пшеничні пластівці. Розсипчаста консистенція готових пластівців спельти була врахована при розробленні рецептури батончиків. 3 метою полегшення їх формування була збільшена в'язкість напівфабрикату за рахунок введення в рецептуру фініків та меду. Рецептура розробленого для ЗРГ кондитерського виробу - батончиків із пластівців спельти - наведена у табл. 7.

Технологія виробництва батончиків із пластівців спельти полягає в наступному: пластівці зі спельти підсушують у пароконвектоматі 2 хв при температурі $120{ }^{\circ} \mathrm{C}$, охолоджують до кімнатної температури. Фініки замочують у теплій воді на 3 хв, висушують паперовим рушником, видаляюь кісточку, подрібнюють. Волоські горіхи та насіння перебирають, контролюють на відсутність шкарлупи та інших сторонніх частинок. Мигдаль замочують на 3 год, обсушують паперовим рушником. Насіння та горіхи бланшують, висушують паперовим рушником, подрібнюють. У чисту суху ємність кладуть усі підготовлені інгредієнти, додають мед та ретельно перемішують 5 хв. Потім формують батончик у вигляді прямокутної форми, i подають.

\section{Таблиця 6}

Показники якості готових пластівців

\begin{tabular}{|c|c|c|c|c|}
\hline \multirow{2}{*}{ Вид пластівців } & \multicolumn{4}{|c|}{ Характеристика готових (зварених) пластівців } \\
\hline & Колір & Смак & Запах & Консистенція після варіння \\
\hline Спельти & $\begin{array}{l}\text { Світло коричневий } \\
3 \text { жовтим відтінком }\end{array}$ & $\begin{array}{c}\text { Приємний, без } \\
\text { гіркоти та сторонніх } \\
\text { присмаків, }\end{array}$ & $\begin{array}{c}\text { Виражений запах } \\
\text { пшениці, з легким } \\
\text { горіховим ароматом }\end{array}$ & $\begin{array}{l}\text { Ніжна, добре розжовується, } \\
\text { без хрусту, розсипчаста }\end{array}$ \\
\hline Вівсяні & $\begin{array}{c}\text { Білий } з \text { відтінками } \\
\text { від кремового до } \\
\text { жовтуватого }\end{array}$ & $\begin{array}{c}\text { Приємний, без } \\
\text { гіркоти та сторонніх } \\
\text { присмаків, }\end{array}$ & Виражений запах вівса & $\begin{array}{c}\text { Ніжна, добре розжовується, } \\
\text { без хрусту, в’язка }\end{array}$ \\
\hline Пшеничні & Світло кремовий & $\begin{array}{c}\text { Властивий пластівцям } \\
3 \text { чітко вираженим } \\
\text { ароматом пшениці }\end{array}$ & $\begin{array}{c}\text { Притаманний пластів- } \\
\text { цям, без гіркого прис- } \\
\text { маку }\end{array}$ & $\begin{array}{c}\text { Добре розжовується, але } \\
\text { пелюстки не зберігають } \\
\text { форму }\end{array}$ \\
\hline
\end{tabular}

Таблиця 7

Рецептура батончиків із пластівців спельти

\begin{tabular}{llcc}
\hline \multirow{2}{*}{$\begin{array}{c}\text { № } \\
\text { п/п }\end{array}$} & \multirow{2}{*}{$\begin{array}{c}\text { Найменування } \\
\text { сировини }\end{array}$} & \multicolumn{2}{c}{ Норма вмісту в готовій } \\
\cline { 3 - 4 } & \multicolumn{2}{c}{ страві або виробі, г } \\
\hline 1 & Пластівці спельти & 15 & Нруто \\
2 & Фініки & 12 & 13 \\
3 & Горіхи грецькі & 7 & 6 \\
4 & Мигдаль & 4 & 4 \\
5 & Насіння гарбуза & 7 & 7 \\
6 & Насіння соняшника & 5 & 5 \\
7 & Мед & 6 & 6 \\
8 & Кунжут & 2 & 2 \\
\multicolumn{2}{c}{ Вихід } & & 50 \\
\hline
\end{tabular}

Готові вироби оцінювали за органолептичними показниками. Батончик із пластівців спельти має прямокутну форму, рифлену без тріщин поверхню; хрумку консистенцію, світло-коричневий колір і виражений горіховий аромат. Зображення готового виробу подано на рис. 2.

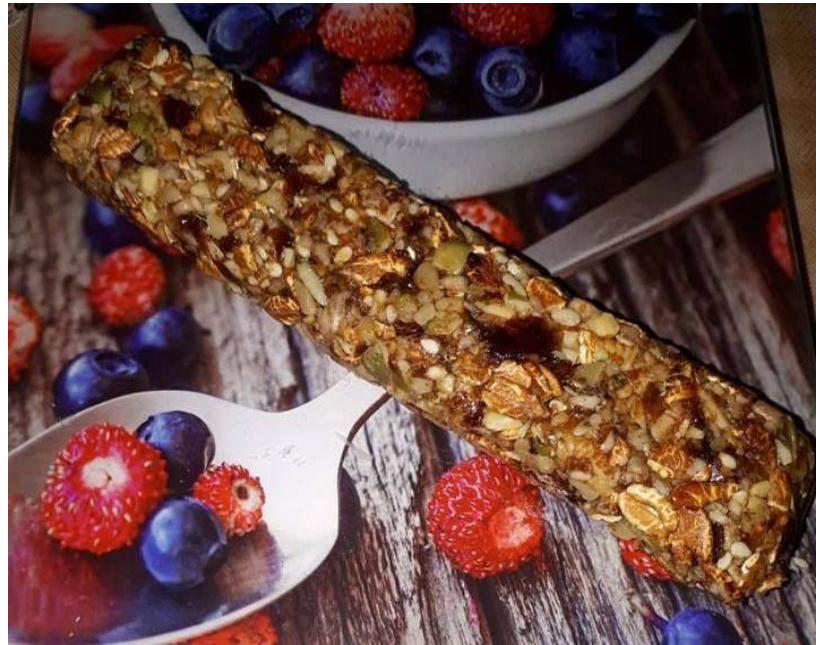

Рис. 2. Батончик із пластівців спельти

Енергетична цінність батончика із пластівців спельти складає 220 ккал.

У готових виробах також визначали мікробіологічні показники якості (табл. 8). 
Таблиця 8

Мікробіологічні показники якості батончика з пластівців спельти

\begin{tabular}{|c|c|c|c|}
\hline $\begin{array}{c}\text { Назва випробувань та характеристика } \\
\text { параметрів, що визначаються }\end{array}$ & $\begin{array}{c}\text { Значення і допуск показника } \\
\text { за ДСТУ 4135:2014 } \\
\text { (не більше) } \\
\end{array}$ & $\begin{array}{c}\text { Результати } \\
\text { випробувань }\end{array}$ & $\begin{array}{l}\text { Нормативний документ } \\
\text { на метод випробуваннь }\end{array}$ \\
\hline $\begin{array}{l}\text { Кількість мезофільних аеробних і факульта- } \\
\text { тивно анаеробних мікроорганізмів, КУО/г }\end{array}$ & $5 \times 10^{4}$ & $3,0 \times 10^{4}$ & ДСТУ 8446:2014 \\
\hline $\begin{array}{l}\text { Патогенні мікроорганізми в т.ч. бактерії роду } \\
\text { Сальммонелла в } 25 \text { г }\end{array}$ & 25,0 & не виявлено & ДСТУ ЕN 12824-2004 \\
\hline Дріжджі, КУО/г & $2 \times 10^{2}$ & $1,5 \times 10^{2}$ & ДСТУ 8447:2015 \\
\hline Плісняві гриби КУО/г & $5 \times 10^{2}$ & $2,5 \times 10^{2}$ & ДСТУ 8447:2015 \\
\hline
\end{tabular}

Аналіз табл. 8 показав, що батончик із пластівців спельти, виготовлений за розробленою технологією, відповідає вимогам нормативних документів і може бути допущений до реалізації у закладах ресторанного господарства.

У процесі зберігання в готових виробах визначали вологість термогравіметричним методом (рис. 3, рис. $4)$.

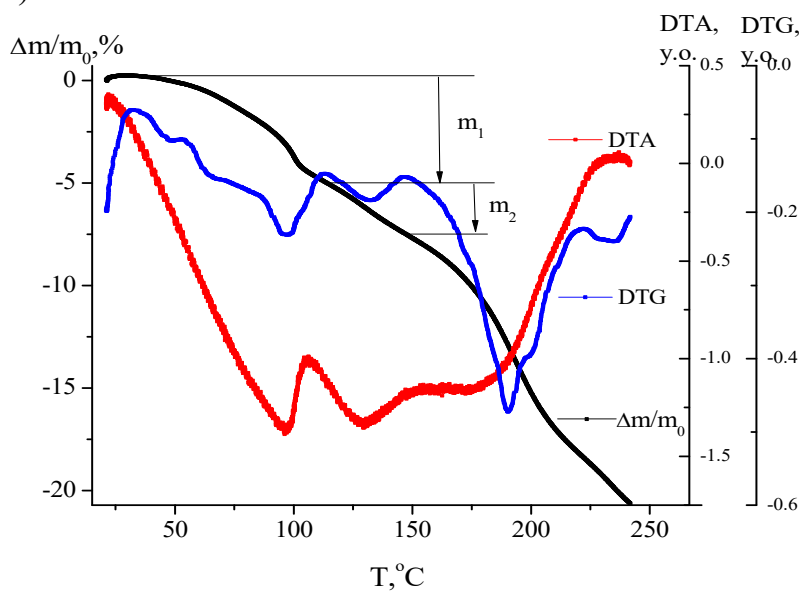

Рис. 3. Температурні залежності втрати маси TG, диференціально-термічного аналізу DTA та похідної від втрати маси DTG для свіжого батончика

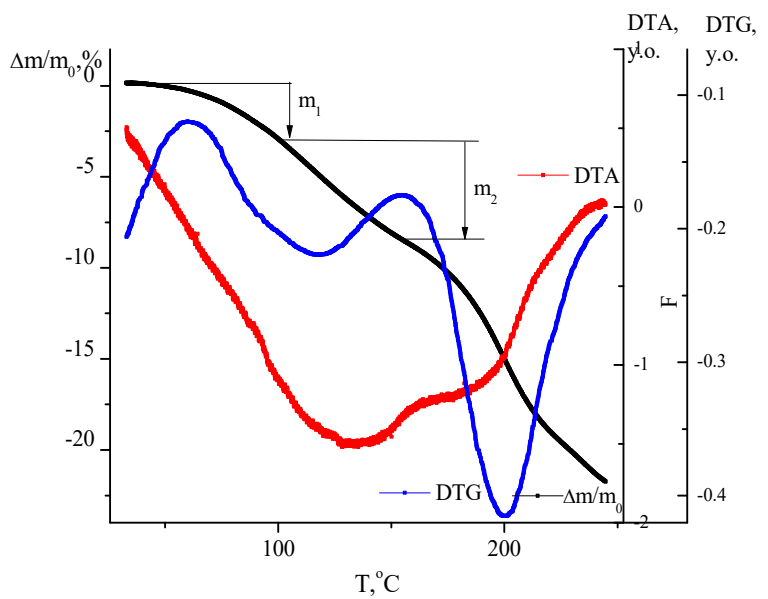

Рис. 4. Температурні залежності втрати маси TG, диференціально-термічного аналізу DTA та похідної від втрати маси DTG для батончика, що зберігався 4 місяці

При нагріванні № 1 в області $\mathrm{T}_{1}=90{ }^{\circ} \mathrm{C}$ та $\mathrm{T}_{2}=125{ }^{\circ} \mathrm{C}$ відбувається втрата маси яка супроводжу- ється ендотермічними піками на залежності DTA. Цю втрату маси можна пов'язати з випаровуванням води. При зростанні температури до $3_{2}=150{ }^{\circ} \mathrm{C}$ в зразку починає відбуватися деструкція

Аналіз рис. 3 і рис.4 показав, що при нагріванні зразка в області $\mathrm{T}_{1}=90^{\circ} \mathrm{C}$ та $\mathrm{T}_{2}=125^{\circ} \mathrm{C}$ відбувається втрата маси для свіжого зразка на $\mathrm{m}_{1}=5 \%$ та $\mathrm{m}_{2}=2,5 \%$, а для збереженого зразка на $\mathrm{m}_{1}=2,8 \%$ та $\mathrm{m}_{2}=5,7 \%$. Ці втрати маси супроводжуються ендотермічними піками на залежності DTA. Їх можна пов'язати з випаровуванням води. При зростанні температури до Т3 $=150{ }^{\circ} \mathrm{C}$ в зразках починає відбуватися деструкція. Значення $\mathrm{m}_{1}$ та $\mathrm{m}_{2}$ відповідно показують вміст вільної і зв'язаної води у батончику. Ці значення змінюються в процесі зберігання. Вільна вода втрачається, що зумовлює втрату органолептичних показників готового виробу.

\section{Висновки}

3 огляду на вище сказане, продукти переробки зерна спельти можуть 3 успіхом використовуватися у ЗРГ для задоволення смаків споживачів, які дотримуються філософії здорового харчування. Розроблені продукти можуть бути впроваджені у закладах ресторанного господарства без додаткових капітальних вкладень. Гарні органолептичні показники хлібців і енергетичних батончиків роблять корисну їжу іще й смачною.

\section{References}

Bonafaccia, G., Gallia, V., Franciscia, R., Mairb, V., Skrabanjac, V., \& Kreft, I. (2000). Characteristics of spelt wheat products and nutritional value of spelt wheat-based bread. Food Chemistry, 68(4), 437-441. doi: 10.1016/S0308-8146(99)00215-0.

Bul'chuk, E.A., \& Nikulin, A.F. (2008). Ispol'zovanie spel'ty $\mathrm{V}$ proizvodstve hlebobulochnyh izdelij. Materialy II Vseros. nauch.-prakt. konf. Molodyh uchenyh i aspirantov, 14-16 apr. 2008, CH 1. Ufa: FGOU VPO "Bashkirskij GAU”, 244-246 (in Russian).

Golik, O.V. (2012). Polba i spel’ta - vy` znayete rizny`cyu? [Internet]. Available from: https:/www.euro-i.org/index.php/uk/stati/357-polba-ispelta-vi-znaete-riznitsyu (in Ukrainian).

Kohajdová, Z., \& Karovičová, J. (2008). Nutritional value and baking applications of spelt wheat. Acta 
Scientiarium Polonorum, Technologia Alimentaria, 7(3), 5-14. https://www.food.actapol.net/pub/ 1_3_2008.pdf.

Ranhorta, G.S., Gerroth, J.A., Glaser, B.K., \& Lorenz, K.J. (1995). Baking and nutritional qualities of a spelt wheat sample. Lebensm. Wiss. Technol, 28(1), 118122. doi: 10.1016/S0023-6438(95)80022-0.

Shewry, P.R. (2018). Do ancient types of wheat have health benefits compared with modern bread wheat? Journal of cereal science, 79, 469-476. doi: $10.1016 /$ j.jcs.2017.11.010. 